\title{
Jaki to rytm serca?
}

\section{What kind of heart rhythm is this?}

\author{
Katarzyna Kolaszyńska ${ }^{1}$, Agata Galas ${ }^{2}$, Jarosław Kowal ${ }^{2}$, Robert Wierzbowski ${ }^{2}$ \\ ${ }^{1}$ Studenckie Kardiologiczne Koło Naukowe CARDIACUS przy Klinice Kardiologii i Chorób Wewnętrznych \\ Wojskowego Instytutu Medycznego w Warszawie \\ ${ }^{2}$ Oddział Kardiologii Nieinwazyjnej i Telemedycyny Kliniki Kardiologii i Chorób Wewnętrznych \\ Wojskowego Instytutu Medycznego w Warszawie
}

\section{Streszczenie}

Pacjent w wieku 81 lat ze złożona wadą serca pod postacią ciężkiej stenozy zastawki aortalnej i niedomykalności zastawki mitralnej (kwalifikowany do przezskórnej implantacja zastawki aortalnej), z przewlekłą niewydolnością serca (II klasa wg New York Heart Association [NYHA]), z wywiadem napadowego migotania przedsionków, cukrzycą typu 2, nadciśnieniem tętniczym i tętniakiem aorty brzusznej został przyjęty do Kliniki Kardiologii i Chorób Wewnętrznych WIM z powodu zaostrzenia niewydolności serca (III/IV klasa wg NYHA). Wcześniej był 2-krotnie hospitalizowany - w elektrokardiogramie (EKG) opisywano tachykardię zatokową. W EKG z kolejnej hospitalizacji opisano częstoskurcz przedsionkowy z blokiem 2:1, z miarową czynnością komór 100/min. Opis przypadku obrazuje trudności w różnicowaniu częstoskurczu przedsionkowego i tachykardii zatokowej.

Słowa kluczowe: ogniskowy częstoskurcz przedsionkowy, tachykardia zatokowa, niewydolność serca, stenoza aortalna

Folia Cardiologica 2015; 10, supl. C: $31-34$

\section{Wstęp}

Ogniskowy częstoskurcz przedsionkowy charakteryzuje się miarową czynnością elektryczną przedsionków o częstości 100-250/min, niepochodzącą z węzła zatokowego ani przedsionkowo-komorowego. Nietrwały częstoskurcz przedsionkowy jest często spotykany w zapisach holterowskich, w większości przypadków ma bezobjawowy przebieg i nie prowadzi do groźnych następstw. Trwały częstoskurcz jest stosunkowo rzadki. Może on jednak prowadzić do wystąpienia kardiomiopatii wywołanej częstoskurczem [1]. Objawami częstoskurczu mogą być kołatania serca, dyskomfort w klatce piersiowej, zasłabnięcia czy duszność [2].

Częstoskurcz przedsionkowy może być spowodowany obecnością wad serca, przedawkowaniem naparstnicy, może się nasilać pod wpływem hipokaliemii bądź też być schorzeniem idiopatycznym. Przejawem częstoskurczu przedsionkowego w zapisie elektrokardiograficznym (EKG) jest występowanie załamka P w drugiej połowie cyklu. Czesto załamek P nakłada się na załamek T, co utrudnia jego dostrzeżenie i prowadzi do błędnego rozpoznania rytmu zatokowego. Występowanie linii izoelektrycznej między załamkami P pozwala odróżnić tę arytmię od trzepotania przedsionków. Obecność bloku przedsionkowo-komorowego wyklucza nawrotny częstoskurcz przedsionkowo-komorowy (AVRT, atrioventricular reentrant tachycardia) i zmniejsza prawdopodobieństwo rozpoznania nawrotnego częstoskurczu przedsionkowo-komorowego węzłowego (AVNRT, atrio-ventricular nodal reentry tachycardia).

Choć ustalenie dokładnego źródła częstoskurczu wymaga badania elektrofizjologicznego, to ocena załamków $P$ w różnych odprowadzeniach pozwala określić w przybliżeniu miejsce powstania częstoskurczu [1]. 


\section{Opis przypadku}

Pacjent w wieku 81 lat, z wadą serca pod postacią ciężkiej stenozy zastawki aortalnej (zakwalifikowany do przezskórnej implantacja zastawki aortalnej [TAVI, transcatheter aortic valve implantation]) i niedomykalności zastawki mitralnej, z przewlekłą niewydolnością serca, napadowym migotaniem przedsionków (leczonym antagonistą witaminy K), cukrzycą typu 2 (leczoną doustnie), nadciśnieniem tętniczym, tętniakiem aorty brzusznej $(55 \times 58 \mathrm{~mm})$, przewlekłym zapaleniem błony śluzowej żołądka, nawrotowym rakiem pęcherza moczowego po 3-krotnej przezcewkowej resekcji guzów pęcherza (TURBT, transurethral resection of the bladders), w trakcie dopęcherzowej immunoterapii szczepem prątka Bacillus Calmette-Guerin (BCG), po tyreoidektomii w 1984 roku oraz po fakoemulsyfikacji zaćmy z implantacją sztucznej soczewki tylnokomorowej w lewym oku został przyjęty do Kliniki Kardiologii i Chorób Wewnętrznych Wojskowego Instytutu Medycznego w Warszawie z powodu zaostrzenia niewydolności serca do III/IV klasy według New York Heart Association (NYHA). Wcześniej był 2-krotnie hospitalizowany w celu kwalifikacji do TAVI. W EKG opisywano tachykardię zatokową.

Przy przyjęciu pacjent był w średnim stanie ogólnym z dusznością spoczynkową. Ciśnienie tętnicze wynosiło 120/80 mm Hg. Czynność serca była miarowa, około 100/ /min. Nad polami płucnymi stwierdzono szmer pęcherzykowy, zaostrzony, z pojedynczymi trzeszczeniami. Saturacja tlenem $\left(\mathrm{O}_{2}\right)$ wynosiła $94 \%$ bez podania tlenu, a po jego podaniu $97 \%$. W badaniach laboratoryjnych stężenie N-końcowego natriuretycznego propeptydu mózgowego (NT-pro-BNP, N-terminal of the pro-brain natriuretic peptide) wynosiło $9862 \mathrm{pg} / \mathrm{ml}$. W badaniu radiologicznym (RTG) klatki piersiowej zobrazowano obustronnie

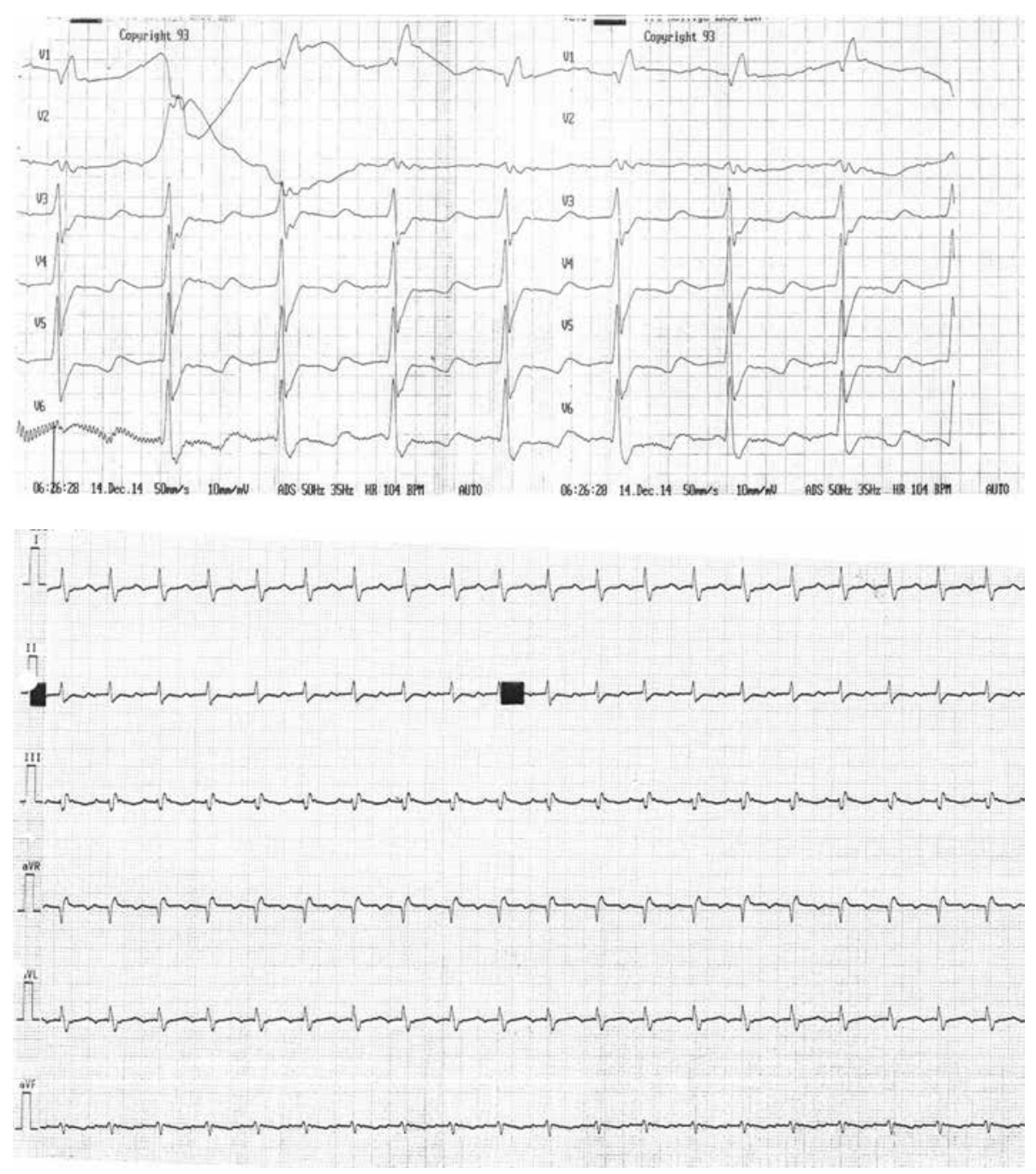

Rycina 1. Dodatkowe załamki P położone za zespołami QRS w odprowadzeniach III, aVL, aVF, V1 i V2 oraz zespoły QRS o morfologii rsr' w odprowadzeniu V2 
ślad płynu w jamach opłucnowych, wzmożony rysunek śródmiąższu - cechy zastoju w krążeniu płucnym, serce powiększone w całości oraz wydłużoną i miażdżycową aortę piersiową. W echokardiografii wykonanej 18 grudnia 2014 roku zaobserwowano pogorszenie w porównaniu z poprzednim badaniem (zmniejszenie frakcji wyrzutowej z $40 \%$ do $24 \%$ ).

W badaniu EKG z 14 grudnia 2014 roku w odprowadzeniach III, aVL, aVF, $V_{1}$ i $V_{2}$ były widoczne dodatkowe załamki P położone za zespołami QRS (ryc. 1). Po dokładnej analizie EKG z 22 września 2014 roku dostrzeżono dodatkowe załamki P w odprowadzeniach III, aVF i V 1 (ryc. 2). W obu zapisach EKG zespoły QRS występowały z częstością 107/ /min, natomiast załamki P - z częstością 214/min. Uwage zwracały również zespoły QRS o morfologii rsr' w odprowadzeniu $V_{2}$ (ryc. 1) oraz zespół QRS o morfologii rSR' w odprowadzeniu $V_{1}$ (ryc. 2) będące obrazem bloku prawej odnogi pęczka Hisa. Skośne do dołu obniżenia odcinka ST świadczyły o przeciążeniu lewej komory.

Rozpoznano częstoskurcz przedsionkowy z blokiem 2:1, miarową czynność komór 107/min, blok prawej odnogi pęczka Hisa i cechy przeciążenia lewej komory. W trakcie hospitalizacji intensyfikowano leczenie niewydolności serca, uzyskując poprawę stanu klinicznego pacjenta.

\section{Omówienie}

Częstoskurcz przedsionkowy występuje u 0,34\% młodych mężczyzn bez objawów kardiologicznych i u 0,46\% pacjentów z objawami. U 37\% po kilku latach dochodzi do spontanicznego powrotu rytmu zatokowego z powodu degeneracji ektopowego źródła pobudzeń [2]. Jednocześnie arytmia ta jest często niewrażliwa na leczenie farmakologiczne.

Pobudzanie nerwu błędnego nie przerywa częstoskurczu przedsionkowego. Skuteczna bywa kardiowersja elektryczna [3]. Jest zalecana u pacjentów niestabilnych hemodynamicznie [1]. W leczeniu pacjentów w stanie stabilnym stosuje się adenozynę, beta-adrenolityki, werapamil, prokainamid, flekainid, propafenon, sotalol, amiodaron [1, 3]. Profilaktyczne leczenie nawracających, objawowych częstoskurczów oraz uporczywych częstoskurczów - zarówno objawowych, jak i bezobjawowych - polega na wykonaniu ablacji przezskórnej. U pacjentów bez objawów z częstoskurczem napadowym nie stosuje się żadnej terapii [1].

Różnorodność przebiegu częstoskurczu przedsionkowego i reakcji na leczenie skłania do wnikliwej analizy stanu pacjenta oraz korzyści i działań niepożądanych terapii. Dodatkowe obciążenia utrudniają podjęcie decyzji o dalszym postępowaniu. Wydaje się, że w opisanym przypadku priorytetem jest korekcja ciężkiej wady zastawkowej i ponowna ocena rytmu oraz stanu pacjenta po zabiegu.

\section{Konflikt interesów}

Autorzy deklarują brak konfliktu interesów.

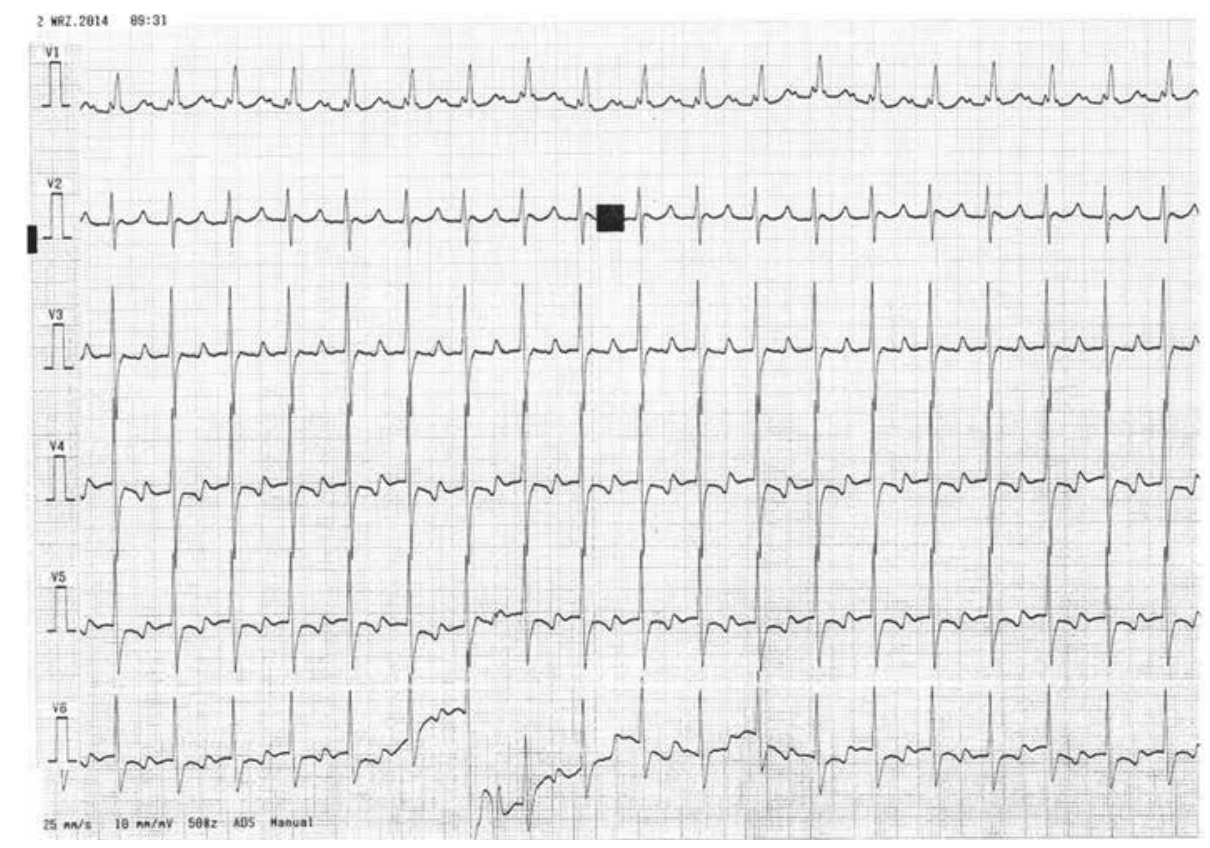

Rycina 2. Dodatkowe załamki P w odprowadzeniach III, aVF i V1 oraz zespół QRS o morfologii rSR' w odprowadzeniu V1 


\section{Abstract}

A 81-year-old man with severe aortic stenosis (qualified for transcatheter aortic valve implantation), mitral insufficiency, chronic heart failure (New York Heart Association [NYHA] II), paroxysmal atrial fibrillation, diabetes mellitus type 2, hypertension, abdominal aortic aneurysm was admitted to the Clinic because of heart failure exacerbation (NYHA III/IV). In the past patient was hospitalized twice - rhythm in electrocardiogram (ECG) was described as sinus tachycardia. During next hospitalization on ECG there was atrial tachycardia with 2:1 block and regular ventricular rate 100/min. This case report demonstrates difficulty in distinguishing sinus tachycardia and atrial tachycardia.

Key words: focal atrial tachycardia, sinus tachycardia, heart failure, aortic stenosis

Folia Cardiologica 2015; 10, supl. C: 31-34

\section{Piśmiennictwo}

1. Blomström-Lundqvist C., Scheinman M.M., Aliot E.M. I wsp. ACC/AHA/ /ESC guidelines for the management of patients with supraventricular arrhythmias - executive summary. JACC 2003; 42: 1493-1531.

2. Poutiainen A.M., Koistinen M.J., Airaksinen K.E. i wsp. Prevalence and natural course of ectopic atrial tachycardia. Eur. Heart J. 1999; 20: $694-700$.
3. Roberts-Thomson K.C., Kistler P.M., Kalman J.M. Atrial tachycardia: mechanisms, diagnosis, and management. Curr. Probl. Cardiol. 2005; 30: 529-573. 